\title{
Physiological Alterations during Pregnancy: Impact on Toxicokinetics
}

\author{
Donald R. Mattison, ${ }^{*}$ Ernice Blann, * and antoine Malek $\dagger$
}

\begin{abstract}
- Deparment of Obstetrics and Gymecology, University of Arkansas for Medical Sciences, Litule Rock, Arkansas 72204, and Division of Reprochictive and Developmental Toxacology. National Center for Toxicological Research. Jefferson. Ankansas 72079; and TDepartment of Obstetrics and Gynecology. Universtly of Berme, Beme. Suitzerland
\end{abstract}

During pregnancy there are physiological changes in several systems which can alter toxicokinetics in both the maternal and fetal compartment (Lewis, 1983; Mattison, 1986) (Table 1). These physiological alterations are required for successful pregnancy and lactation and result from resetting of maternal homeostatic mechanisms to deliver essential nutrients to the fetus and remove heat, carbon dioxide, and waste products from the fetus. The strategies selected by a given species for adaptation to pregnancy (Table 2) appear to depend upon the energy costs of pregnancy (Millar, 1976, 1980; Metcalf et al., 1988). The energy costs of the physiological adaptations of pregnancy are not surprising given that the time from conception to weaning typically represents $3 \%$ of the total life span of an animal and during that time approximately $20 \%$ of the adult weight is developed (Peters, 1983).

\section{GASTROINTESTINAL ALTERATIONS}

In the human, intestinal motility is decreased and gastric emptying time increased (Hytten, 1980a). As a result of these changes in gut motility, xenobiotics will spend a longer time in both the stomach and the small intestine. If the xenobiotic is absorbed through the small intestine, increased residence time in the stomach may delay the time to peak concen- tration in the maternal compartment. In addition, the xenobiotic may be metabolized in the stomach so that increased residence time will decrease the amount of parent compound available for absorption. If the ingested xenobiotic passes through the stomach unal-

\section{TABLE 1}

Physiological Changes Which May alter TOXICOKInETICS DURING PREgnanCy

\begin{tabular}{ll}
\hline & Change \\
\hline Absorption & \\
Gastric emptying time & Increased \\
Intestinal motility & Decreased \\
Pulmonary function & Increased \\
Cardiac output & Increased \\
Blood flow to skin & Increased \\
Distribution & \\
Plasma volume & Increased \\
Total body water & Increased \\
Plasma proteins & Decreased \\
Body fat & Increased \\
Metabolism & \\
Hepatic metabolism & \pm \\
Extrahepatic metabolism & \pm \\
Plasma proteins & Decreased \\
Excretion & \\
Renal blood flow & Increased \\
Glomerular filtration rate & Increased \\
Pulmonary function & Increased \\
Plasma proteins & Decreased \\
\hline
\end{tabular}


TABLE 2

Fetal Growth Characteristics of Selected Mammals

\begin{tabular}{|c|c|c|c|c|}
\hline Characteristic & Human & - Sheep & $\begin{array}{l}\text { Guinea } \\
\text { pig }\end{array}$ & Rat \\
\hline \multicolumn{5}{|l|}{ Description of gestation } \\
\hline Number of fetuses & I & 1 & $3(2-5)$ & $11(10-12)$ \\
\hline Length of fetuses $(\mathrm{mm})$ & 280 & 147 & 67 & 21.5 \\
\hline Growth rate $(\mathrm{g} / \mathrm{kg} /$ day $)$ & 15 & 45 & 70 & 350 \\
\hline Maternal pregravid wt (kg) & 55 & 50 & 0.8 & 0.3 \\
\hline Birth weight (kg) & 3.5 & 3.5 & 0.09 & 0.005 \\
\hline \% maternal pregravid wt & 0.6 & 7 & 34 & 18 \\
\hline \multicolumn{5}{|c|}{ Components of birth weight (\$) } \\
\hline Dry weight & 30 & 19 & 25 & 14 \\
\hline Fat & 16 & 2 & 12 & 1 \\
\hline Protein & 12 & 12 & 12 & 12 \\
\hline Nonfat dry weight & 14 & 16 & 14 & - \\
\hline Placental weight (g) & 550 & 400 & 6.5 & 0.5 \\
\hline \multicolumn{5}{|l|}{$\begin{array}{l}\text { Energy cost of tissue accretion } \\
\text { at term (kcal/fetus) }\end{array}$} \\
\hline Fat & $5320(560 \mathrm{~g})$ & $665(70 \mathrm{~g})$ & $104(11 \mathrm{~g})$ & $0.5(0.05 \mathrm{~g})$ \\
\hline Protein & $2350(420 \mathrm{~g})$ & $2350(420 \mathrm{~g})$ & $62(11 \mathrm{~g})$ & $3.4(0.6 \mathrm{~g})$ \\
\hline \multicolumn{5}{|l|}{ Total } \\
\hline Per fetus & 7670 & 3015 & 166 & 3.9 \\
\hline Per litter & 7670 & 3015 & 498 & 42.9 \\
\hline
\end{tabular}

Note. From Metcalf et al (1988).

tered, the longer time in the small intestine will increase the fraction of xenobiotic absorbed.

\section{CARDIOVASCULAR ADAPTATIONS}

Cardiovascular adaptations are thought to be important to establish adequate uterine

TABLE 3

\begin{tabular}{lccc}
\multicolumn{4}{c}{ Maternal Cardovascular adaptation } \\
\hline & $\begin{array}{c}\text { Cardiac } \\
\text { output ( } \%)\end{array}$ & $\begin{array}{c}\text { Heart } \\
\text { rate }\end{array}$ & $\begin{array}{c}\text { Stroke } \\
\text { volume }\end{array}$ \\
\hline Human & +50 & $+30 \%$ & $+35 \%$ \\
Sheep & +30 & + & + \\
Guinea pig & +20 & - & + \\
Goat & +20 & \pm & \pm \\
Rabbit & +20 & \pm & \pm \\
\hline
\end{tabular}

blood flow (Moawad and Lindheimer, 1982), provide for fetal heat loss, and prepare the mammary gland for lactation (deSwiet, 1980a). In the human, cardiac output increases approximately $50 \%$ (1.5 liter/min) (deSwiet, 1980a). This increase occurs by the end of the first trimester and remains elevated over the remainder of pregnancy. Cardiac output is composed of two components: stroke volume (the amount of blood pumped with each beat) and heart rate. In the human the increase in cardiac output is accomplished by an increase in both stroke volume and heart rate (Table 3). Other animals, however, use different mechanisms to increase cardiac output in pregnancy. Increased cardiac outputs lead to an increase in blood flow to the uterus at term (Moawad and Lindheimer, 1982; Metcalf et al., 1988). In women, uterine blood flow at the end of pregnancy is about $150 \mathrm{ml} / \mathrm{kg} / \mathrm{min}$. 
TABLE 4

Maternal PUlmonary adaptation

\begin{tabular}{lccc}
\hline \multicolumn{1}{c}{ Function } & Nonpregnant & Pregnant & Change (\$) \\
\hline Respiratory rate & 15 & 16 & \pm \\
Tidal volume $(\mathrm{ml} / \mathrm{min})$ & 487 & 678 & +39 \\
Minute ventilation $(\mathrm{ml})$ & 7270 & 10,340 & +42 \\
Minute $\mathrm{O}_{2}$ uptake & 201 & 266 & +32 \\
Vital capacity $(\mathrm{ml})$ & 3260 & 3,310 & +1 \\
\hline
\end{tabular}

Note. Data from deSwiet (1980b).

This is comparable to uterine blood flow in the guinea pig, rabbit, and rhesus monkey ( 100 $\mathrm{ml} / \mathrm{kg} / \mathrm{min})$, but considerably below those of sheep and goats $(300 \mathrm{ml} / \mathrm{kg} / \mathrm{min})$.

In women, maternal blood volume increases about $50 \%$, comparable to the increase observed in guinea pigs. Rabbits, sheep, and rats, however, appear to have smaller increases in blood volume during pregnancy. In all species studied, peripheral vascular resistance decreases during pregnancy. However, in humans after mid-gestation (20 weeks), peripheral vascular resistance begins to increase, and at term is at or above the peripheral vascular resistance at the start of pregnancy.

There are also substantial changes in blood flow to different regions of the body during pregnancy. Blood flow to the hand increases

TABLE 5

INCREMENT OF OXYGEN CONSUMPTION $(\mathrm{ml} / \mathrm{min})$

\begin{tabular}{lcccc}
\hline & \multicolumn{4}{c}{ Weeks of gestation } \\
\cline { 2 - 5 } & 10 & 20 & 30 & 40 \\
\hline Cardiac output & 4.5 & 6.8 & 6.8 & 6.8 \\
Respiration & 0.8 & 1.5 & 2.3 & 3.0 \\
Renal (Na) & 7 & 7 & 7 & 7 \\
Uterus & 0.5 & 1.2 & 2.2 & 3.6 \\
Placenta & 0.0 & 0.5 & 2.2 & 3.7 \\
Fetus & 0.0 & 1.1 & 5.5 & 12.4 \\
Breasts & 0.1 & 0.6 & 1.2 & 1.4 \\
Total increment & 12.9 & 18.7 & 27.2 & 37.9 \\
\hline
\end{tabular}

Note. Modified from Hytten and Chamberlain (1980). approximately sixfold ( 3 to $18 \mathrm{ml} / \mathrm{min} / 100 \mathrm{ml}$ tissue) during pregnancy (de Swiet, 1980a), and blood flow to the foot doubles ( 2.5 to 5 $\mathrm{ml} / \mathrm{min} / 100 \mathrm{ml}$ tissue). Over this same period of gestation there are only small increases in blood flow to the forearm and leg.

\section{RENAL ADAPTATIONS}

In the human and the rat, renal blood flow increases during pregnancy. In rabbits, guinea pigs, and sheep, however, renal blood flow appears to remain unchanged during pregnancy (Davison, 1980; Metcalf et al., 1988). One result of the increased renal blood flow during pregnancy in the human is an increase in renal size and energy utilization. The increase in renal size and energy utilization is a direct consequence of the increased renal blood flow. The increase in renal blood flow increases the glomerular filtration rate which removes increasing amounts of sodium. As sodium is the major extracellular solute it must be reabsorbed. In addition to the increase in reabsorption, the 6 to 8 liter increase in total body water requires an increase in sodium reabsorption. These alterations in renal blood flow and glomerular filtration rate may alter maternal renal xenobiotic elimination (Lewis, 1983; Mattison, 1986).

\section{RESPIRATORY ADAPTATION}

Pulmonary function also changes significantly during pregnancy (Table 4). Although 
the respiratory rate is unchanged (deSwiet, $1980 \mathrm{~b}$ ), the tidal volume is increased. An increase in minute ventilation during pregnancy has also been observed in goats, sheep, cows, guinea pigs, and rats (Metcalf et al., 1988). As a result of the increase in tidal volume there is an increase in the pulmonary distribution of gases, increased alveolar mixing, and a decrease in the time to reach alveolar steady state. Gas transfer, however, appears to be decreased due to interstitial changes in the lungs during pregnancy. For example, the pulmonary diffusing capacity of carbon monoxide is decreased from 26.5 to $22.5 \mathrm{ml} / \mathrm{min} / \mathrm{mm} \mathrm{Hg}$.

The increased minute oxygen uptake is reflected in decreased arteriovenous differences in $p \mathrm{O}_{2}$ during pregnancy and in increased oxygen consumption of approximately $40 \mathrm{ml} /$ min (Hytten and Chamberlain, 1980). The components of the increased oxygen consumption early in pregnancy are predominantly cardiac output and renal sodium reabsorption. At term, however, the fetus, placenta, and uterus account for a substantial portion of the increase in oxygen consumption ( $\mathrm{Ta}$ ble 5).

\section{SUMMARY}

The physiological changes that occur in the alimentary, cardiovascular, pulmonary, and renal organ systems during pregnancy are designed to increase availability of nutrients to and remove wastes from the fetus. Although this is a general requirement, not all animals use the same strategies to meet these goals. These physiological adaptations will impact on toxicokinetics and may alter toxicodynamics. Absorption, distribution, metabolism, transfer between maternal and fetal compartments, and elimination will change for many xenobiotics during pregnancy. The changes in body weight, total body water, plasma proteins, body fat, and cardiac output will alter the distribution of many xenobiotics (Hytten and Leitch, 1971; Hytten and Chamberlain, 1980; Mattison, 1986). As the toxicokinetic parameters change across species, it is important to understand their impact on chemicals associated with maternal, placental, and fetal toxicity for appropriate cross-species extrapolation.

\section{REFERENCES}

Davison, J. M. (1980). The urinary system. In Clinical Physiology in Obstetrics (F. E. Hytten and G. Chamberlain, Eds.), pp. 289-327. Blackwell, Oxford.

DESWIET, M. (1980a). The cardiovascular system. In Clinical Phystology in Obstetrics (F. E. Hytten and G. Chamberlain, Eds.), pp. 3-42. Blackwell, Oxford.

DESwIET, M. (1980b). The respiratory system. In Clinical Phystology in Obstetrics (F. E. Hytten and G. Chamberlain, Eds.), pp. 79-100. Blackwell, Oxford.

HYTTEN, F. E. (1980a). The alimentary system. In Clinical Physiology in Obstetrics (F. E. Hytten and G. Chamberlain, Eds.), pp. 147-162. Blackwell, Oxford.

HYTTEN, F. E. (1980b). Weight gain in pregnancy. In Clinical Physiology in Obstetrics (F. E. Hytten and G. Chamberlain, Eds.), pp. 193-233. Blackwell, Oxford.

Hytten, F. E., and Chamberlain, G. (1980). Clinical Physiology in Obstetrics. Blackwell, Oxford.

LEWIS, P. J. (1983). Clinical Pharmacology in Obstetrics. Wright PSG, Boston.

MATTISON, D. R. (1986). Physiological variations in pharmacokinetics during pregnancy. In Drug and Chemical Action in Pregnancy (S. Fabro, A. R. Scialli Eds.), pp. 37-102. Dekker, New York.

MEtCalF, J., STOCK, M. K., AND BarRoN, D. H. (1988). Maternal Physiology during Gestation. In The Physiology of Reproduction (E. Knobil and J. Neill, Eds.), pp. 2145-2176. Raven Press, New York.

Millar, J. S. (1976). Adaptive features of mammalian reproduction. Evolution 31, 370-386.

MILlaR, J. S. (1980). Pre-partum reproductive characteristics of eutherian mammals. Evolution 35(6), 11491163.

MOAWAD, A. H., AND LINDHEIMER, M. D. (1982). Uterine and Placental Blood Flow. Masson, New York.

Peters, R. H. (1983). Cambridge Studies in Ecology: The Ecological Implicatıons of Body Size. Cambridge Univ. Press, Cambridge. 